Humaniora. Czasopismo Internetowe

$\mathrm{Nr} 3(31) / 2020$, ss. 15-26

MONIKA OLIWA-CIESIELSKA

Uniwersytet im. Adama Mickiewicza w Poznaniu

Wydział Socjologii

e-mail: moliwa@amu.edu.pl

ORCID: 0000-0002-1041-9812

\title{
Teoretyczne ujęcia i egzemplifikacje wykluczenia społecznego
}

\begin{abstract}
The article presents problems with the theoretical distinction between social exclusion and marginalization, pointing to the proposals of contemporary approaches and references to ambiguously used and abused constructs. The key is to point out that exclusion and marginalization are not a separate problem, but always conditioned by specific social problems, dysfunctions and deficiencies. A separate feature is the separable nature of the highlighted problems, because in social life they are often mutually conditioning areas, which in the case of the occurrence of broadly understood dysfunctions, focus on various severities. The analysis of marginalization and exclusion also shows the problem of building boundaries between these two concepts but also those suppressing excessive inclusion of concepts. The problems contained in the article indicate that researchers are trying to characterize these concepts separately for the purposes of their own analysis, but in common use there is no unified understanding of the term neither marginalization nor exclusion. The article also shows contemporary references to areas of exclusion, which has lost its legal basis in favor of economic and mental isolation processes.
\end{abstract}

Keywords: social exclusion, marginalization, social participation, social inclusion

$\mathrm{O}$ becnie zarówno w analizach teoretycznych, jak i w działaniach praktyków skupionych na pomocy jednostkom umieszczanym w „obszarze problemów społecznych”1 stosuje się częściej określenie wykluczenia, niejako pomijając mar-

${ }^{1}$ M. Piorunek (red.), Społeczne i jednostkowe konteksty pomocy, wsparcia społecznego i poradnictwa, t. 1, Wydawnictwo Naukowe UAM, Poznań 2018. 
ginalizację, jednocześnie nie wyodrębnia się wykluczenia jako sytuacji życiowej innej od marginalizacji. W literaturze wyjaśniającej różnice między nimi trudno dostrzec ich rzeczywistą rozłączność. Według Tadeusza Kowalaka wykluczenie i marginalizacja są synonimami. Wykluczenie (ang. exclusion) przyjęło się z literatury francuskojęzycznej, a marginalność i marginalizacja (ang. marginality, marginalization) pochodzi z ustaleń anglojęzycznych ${ }^{2}$. Pojęcie wykluczenia jest obecne w debacie od ponad 30 lat, w przeciwieństwie do anglosaskiego terminu „marginalizacja”, który - jak wskazuje Elżbieta Tarkowska - w naukach społecznych i w kontekstach publicznych jest obecny w kręgu europejskim od lat 70. XX wieku's

Rozgraniczenie pojęć wykluczenia i marginalizacji nastręcza wiele problemów, zwłaszcza jeśli poszukuje się naukowego podejścia definiującego te sytuacje. Również w potocznym rozumieniu i publicystycznych opisach w natłoku egzemplifikacji traktuje się je jako sytuacje, które nie dają się jednoznacznie rozgraniczać. Jest to rzeczywiście trudne, ponieważ można przyjąć, że stan marginalizacji powoduje wykluczenie bądź czasowo jest stanem wykluczenia lub też stanem wykluczenia w niektórych sferach życia, a wykluczenie jednoznacznie świadczy o marginalizacji. Teoretyczne rozstrzyganie o niuansach w tych określeniach przyjmuje się jako porządkujące, jednak niemożliwe do jednoznacznego zastosowania wobec złożonych problemów życia ludzi. Na poziomie teoretycznym można przyjąć, że marginalizacja oznacza usytuowanie na peryferiach życia społecznego, które jeszcze nie całkiem jest dla jednostki czy grupy stracone, natomiast wykluczenie oznacza brak możliwości uczestnictwa w nurtach życia społecznego, czyli znalezienie się poza życiem społecznym (co również przez wielu podawane jest w wątpliwość jako niemożliwe) ${ }^{4}$. W takim znaczeniu wykluczenie oznacza izolację czy też wyizolowanie - a są to pojęcia używane także w odniesieniu do marginalizacji, często stosowane do charakterystyki życia jednostki, podkreślającej jej obcość wśród innych.

Śledząc bogatą literaturę na temat wykluczenia i marginalizacji, można zauważyć, że nadal trwa dyskusja nad zakresem definicji problemu wykluczenia i marginalizacji ${ }^{5}$. Wynika z niej jednak, że nie można mówić o ich jednoznacznej rozłączności, z tego względu jest dopuszczalne używanie ich jako synonimów. W jednym i drugim obszarze znaczeń obserwuje się w kontekstach teoretycznych i narracji publicznej wiele nadużyć. Z kierunku zmian w postrzeganiu wykluczenia i marginalizacji wynika, że marginalizacja jako proces, który odnosi się do jed-

2 T. Kowalak, Marginalność i marginalizacja społeczna, Dom Wydawniczy Elipsa, Warszawa 1998, s. 29.

${ }^{3}$ E. Tarkowska, Ubóstwo i wykluczenie społeczne. Koncepcje i polskie problemy, w: J. Wasilewski (red.), Współczesne społeczeństwo polskie. Dynamika zmian, Scholar, Warszawa 2006.

${ }^{4}$ E. Wnuk-Lipiński, Socjologia życia publicznego, Scholar, Warszawa 2005, s. 271.

${ }^{5}$ M. Michel, Gry uliczne w wykluczenie społeczne w przestrzeni miejskiej. Perspektywa resocjalizacyjna, Wydawnictwo Uniwersytetu Jagiellońskiego, Kraków 2016, s. 73 nn. 
nostek i grup społecznych, nie wyraża ich trwania w mniejszości. Marginalność nie jest stanem umykającym uwadze innych, stanem, któremu nie przypisuje się znaczenia i wagi. Gdyby marginalizacja oznaczała jedynie mniejszość lekceważoną, trudności pojawiłyby się w zaklasyfikowaniu do zmarginalizowanych znacznej liczby osób żyjących w skrajnym ubóstwie, w polskich kulturowo-społecznych warunkach.

Takie spojrzenie unika nieuprawnionego, arbitralnego, sugerującego rodzaj „nowego manicheizmu” podziału na tych, którzy są wykluczeni z danego obszaru życia społecznego, i na tych, którzy przynależą.

Od lat niezmienne jest to, że wykluczenie społeczne (charakteryzowane czasem zamiennie jako marginalizacja) jest trwałą cechą rzeczywistości społecznej. Oznacza ono nieuczestnictwo społeczne, a tym samym niemożność korzystania przez jednostki i grupy z dóbr uznanych w danych warunkach kulturowo-społecznych za istotne dla rozwoju jednostkowego i społecznego. Wykluczenie i marginalizacja należą także do obszaru moralności, ponieważ ich istnienie jest trudne do pogodzenia z poczuciem jakkolwiek definiowanej sprawiedliwości. Zasięg wykluczenia i jego głębokość nie jest obojętny dla kształtu życia społecznego w jakimkolwiek społeczeństwie czy społeczności.

Wykluczenie jest sytuacją niemożności podjęcia przez jednostki i grupy działań, w sferze, w której są one uzasadnione społecznie. Nie jest ono wiązane jedynie z aspektami ekonomicznymi, powodują je bowiem oprócz ekonomicznych także pozaekonomiczne braki i niedostatki (nawet jeśli ich podłoże jest stricte ekonomiczne) ${ }^{6}$.

W analizach dotyczących wykluczenia silny nacisk kładziony jest na szanse uczestniczenia jednostek w życiu społecznym, niezależnie od problemu, który dotyka jednostki, a który staje się główną przyczyną wykluczenia. Socjologowie podkreślają wzajemne warunkowanie procesów marginalizowania i samomarginalizacji jednostek i grup, zakładając współudział (sprawstwo) społeczeństwa w ograniczeniu dostępu do określonych dóbr i usług czy uczestnictwa w obszarach wyznaczających pozycję społeczną.

Traktowanie wykluczenia jako nieuczestniczenia jednostek w życiu społecznym jest bardzo ogólnym wyznacznikiem. Cechy określające wykluczenie i marginalizację są porządkujące, gdy zostaną opatrzone zastrzeżeniem, że potrzebne do ich identyfikacji są wskaźniki, co jest jednostce „należne”, czego została ona pozbawiona. Należy mieć na uwadze, iż brak uczestnictwa powinien być rozpatrywany jedynie w sferach, w których kulturowo-społecznie przyjęte normy, wzory i wartości wskazują, iż w danej sferze życia oczekiwane jest uczestnictwo jednostki. Wiąże się to także z oceną kompetencji jednostki do pełnienia określonych ról

${ }^{6}$ Por. G. Firlit-Fesnak, Bieda i płeć. Sfery podziału kreujqce ubóstwo kobiet w krajach Unii Europejskiej, Oficyna Wydawnicza Aspra-JR, Warszawa 2015. 
społecznych i tworzenia adekwatnych do nich warunków, a w przypadku ograniczonych kompetencji - tworzenia systemowych rozwiązań do ich nabywania.

W najszerszym rozumieniu w zbiorowości marginalnej znajdują się ci, którzy:

1. Nie mają możliwości uczestniczenia w życiu społecznym, a chcieliby w nim uczestniczyć.

2. Nie mają możliwości uczestniczenia w życiu społecznym i nie chcieliby z różnych powodów (argumentowanych bądź nie, realnych lub wyimaginowanych) w nim uczestniczyć.

Definicyjne zakresy pojęć wykluczenia i marginalizacji wskazują na złożoność problemu, w którego analizie należy brać pod uwagę przede wszystkim wielość sfer życia jednostek - wielość obszarów wykluczenia, a także różnorodny zakres wykluczenia i jego głębokość. Wyodrębnione obszary do dogłębnej diagnozy wykluczenia, określane jako problemowe, są w różnym stopniu nacechowane dotkliwością, mają różny zakres, a także różny stopień wpływu na społeczną destabilizację. Ich wspólną cechą jest jednak balansowanie jednostek umieszczanych w obszarach problemowych między wykluczeniem a integracją społeczną, między byciem w społecznej przestrzeni a samotnością ${ }^{7}$, co w głównej mierze zależy od społecznej kontroli i reakcji na dane problemy. Poszczególne problemy powinny być wpisane w analizy możliwości przeciwdziałania im lub choćby ograniczania ich negatywnych skutków, głównie z tego powodu, że zagrażają trwałym wykluczeniem jednostek i grup.

Marginalizacja i wykluczenie społeczne stały się współcześnie trwałymi cechami rzeczywistości społecznej. Często używanie tych określeń, niezgodne z ich naukową charakterystyką, przyczynia się do nieuprawnionego, powszechnego poszukiwania negatywnych skutków marginalizacji nawet tam, gdzie nie jest ona realna. Wprawdzie obecnie problemy marginalizacji i wykluczenia należy analizować także w kontekście ich trwałości w rzeczywistości społecznej w Polsce, warto jednak pamiętać także o błędnych kwalifikacjach do jej obszarów kategorii społecznych niewskazujących na cechy marginalizacji czy wykluczenia. Płynne rozumienie tych kategorii pojęciowych, wykorzystywanie ich w debacie i wiązanie z różnorodnymi problemami społecznymi jest skutkiem zgody na ich nadmierną inkluzyjność. Swobodne interpretacje znaczeń marginalizacji i wykluczenia, jakie od lat mają miejsce nawet w debatach naukowych i, co oczywiste, pozanaukowych, utrudniają jednoznaczne definiowanie tych kategorii.

Dawne problemy związane z wykluczeniem i marginalizacją ciągle są aktualne, do nich dochodzą nowe aspekty tworzenia problemów, które przejawiają się np. w gettoizacji, która w Polsce ma miejsce przez dążenie do różnicowania przestrzeni, jej waloryzowania i segregowania dla poszczególnych kategorii społecznych. Oprócz tych nowych aspektów są jeszcze nowe trendy, wskazujące na banalizację wykluczenia i marginalizacji, które można dostrzec w kreowanych

\footnotetext{
${ }^{7}$ Por. G. Minois, Historia samotności i samotników, Aletheia, Warszawa 2018, s. 549 nn.
} 
stylach zachowań (np. freeganie), karykaturalnie odzwierciedlających sposób funkcjonowania przypisywany dotąd skrajnie ubogim. Wszystko to przekonuje, że wykluczenie i marginalizacja są terminami, które współcześnie wymagają szczególnej uwagi w odczytywaniu ich znaczeń. Obecnie w debacie publicznej pojęcie wykluczenia pojawia się bardzo często w dość enigmatycznym znaczeniu, zarówno dla jego odbiorców, jak i nadawców. Głównie przekaz ten ma wskazywać na kategorie społeczne, które określane mianem wykluczonych zyskałyby konkretne profity.

Obecnie doświadczenie przez jednostkę marginalizacji, inności, wycofania i wyobcowania ukazane jest w różnych aspektach i niekoniecznie musi być to związane z izolacją w dosłownym znaczeniu. W szerszym rozumieniu „inność” jest czymś więcej niż niemożnością przekazywania doświadczeń, doznań i przeżyć. Marginalizowanie i wycofanie we współczesnej myśli filozoficznej trafnie oddaje Tischnerowska „ucieczka człowieka od człowieka”. Ucieczka ta może być ujmowana w dwóch aspektach: jako uciekanie od widoku drugiej osoby, a także jako zerwanie więzów dialogu ${ }^{8}$. Pierwsza relacja zakłada także dystans fizyczny między jednostkami: „Uciec znaczy tu: oddalić się lub oddalić drugiego poza granice doświadczenia intencjonalnego, wyrzucić poza horyzont świata otaczającego”. Druga forma ucieczki stanowi bezpośrednią niechęć porozumienia, okazywanie braku gotowości do dialogu i konsensusu. Jak wskazuje Tischner: „Kto ucieka od innego człowieka, zrywając więzy dialogu, ten dąży do tego, by radykalnie zamknąć się na niego" ${ }^{10}$.

Obydwie formy ucieczki i niechęci do dialogu ściśle się ze sobą łączą. Bezpośrednia izolacja w sensie fizycznym jest tożsama z zamknięciem na porozumienie. Ucieczki te mogą mieć różne podłoże. Najczęściej podstawą do myślenia jednostki o konieczności ucieczki jest przeświadczenie, że drugi człowiek nie jest godny uwagi, a w skrajnych ocenach, że nosi w sobie znamiona zła. Poczucie zagrożenia i przeświadczenie o możliwości doznania krzywdy jest w tym wypadku kluczowe, stanowi podstawę alienacji, odosobnienia, separacji. Jest to początkiem popadania przez jednostki w coraz szersze sfery wyizolowania - od innych i od siebie - co graniczy z poczuciem bezsensu i brakiem działania społecznego.

Wykluczenie i marginalizacja nie są utożsamiane z fizycznym wydaleniem jednostki ze społeczności. Można też wskazać, że dziś znaczenia nabrała mentalna izolacja innych, która ma podłoże ekonomiczne i która jest wstawiania w miejsce dawnych ograniczeń prawnych. W przypadku niektórych kategorii społecznych izolacja jednak nadal może przybierać tak skrajne formy, jak fizyczne oddzielenie. Faktyczna izolacja np. osób bezdomnych być może nie jest dostrzegana, ale demonstrowana przez wiele osób niechęć do przebywania bezdomnych w miejscach

\footnotetext{
8 J. Tischner, Filozofia dramatu, Znak, Kraków 1999, s. 180.

${ }^{9}$ Ibidem, s. 181.

${ }^{10}$ Ibidem.
} 
publicznych wskazuje na chęć ich izolacji w sensie fizycznym. Problem wykluczenia przez innych w zasadzie dotyczy większości sfer życia bezdomnych. Jest to stan wykorzenienia, nieuczestniczenia jednostek w instytucjonalnym porządku społecznym.

Większa przepuszczalność struktury społecznej, która w normalnych warunkach daje szanse awansu, u wykluczonych wywołuje wzrost niepewności i dążność do utrzymywania obecnego, przewidywalnego miejsca w strukturze społecznej. Daje im to poczucie bezpieczeństwa, które odnajdują w stagnacji, i poczucie zagrożenia, które widzą w zmianie. Dzięki temu jednostka wykluczona zyskuje zwolnienie z obowiązku działania, usprawiedliwiając się niemożnością zmiany sytuacji. Odmienną kwestią jest tu zaniechanie starań z powodu braku efektów podejmowanych zmian. Zachowanie osób wykluczonych wskazuje, iż trwanie w tym położeniu pozwala na poczucie, a czasem na demonstrowanie zniecierpliwienia własną sytuacją. Najczęściej jednak rezultatem identyfikacji własnej deprywacji nie jest wzmożony wysiłek w kierunku poprawy losu, a przeciwnie - obronna reakcja wycofania. Winne temu są często doświadczenia wykluczonych, dające pewność, że zgoda na status napiętnowanego daje większe korzyści niż trudy udowadniania, że piętnujący nie mają racji. Takie zachowanie jest o tyle racjonalne, iż daje jednostkom namiastkę przewidywalności własnego losu. Przewidują zatem, że niepowodzenia są w wielu przypadkach nieuniknione, należy więc tylko na nie oczekiwać.

W analizie marginalizacji warto wskazać na społeczny kontekst i zmienne interpretacje, jakie towarzyszą teoretycznym rozstrzygnięciom dotyczącym tego, kogo uznać za wykluczonego. Niektóre analizy dopatrują się w kategoriach marginalizacji pozytywnych aspektów, np. wskazania Roberta E. Parka, który twierdzi, że jednostki marginalne to osoby o szerszych horyzontach, „wyzwolone osobowości” czy „kulturowe hybrydy”. Są to ludzie, których można za Parkiem określić jako „żyjących w dwóch odmiennych społecznościach i głęboko uwikłanych w kulturę i tradycję każdej z nich”"11. Porządkujące analizy dotyczące marginalizacji, jakie poczynił Kazimierz W. Frieske, wskazują, że współczesne rozumienie osoby wykluczonej i marginalizowanej także jako „obcej” zmieniło nieco wydźwięk przypisywanych jej cech, nadając jej miano nie obcego, ale innego. Pojęcie to nabrało raczej znaczenia określonego w kategoriach „ułomności”" Podobne ustalenia pozwoliły analizować wykluczenie i marginalizację w kategoriach odnoszących się do wartości, skoro wskazuje się na nieaprobowane społecznie zachowanie braku działań, beznadziejności, uległości, które są przywoływane najczęściej w kontekstach dysfunkcjonalności wobec społecznego rozwoju. Dało to szansę na traktowanie obszaru marginalizacji jako problemu społecznego, a nie jedynie

${ }^{11}$ R.E. Park, Human Migration and the Marginal Man, „American Journal of Sociology” 33(8)/1928.

${ }^{12}$ K.W. Frieske (red.), Marginalność i procesy marginalizacji, IFiS PAN, Warszawa 1999, s. 12. 
jako obszaru interesującego poznawczo. Takie podejście pozwala zauważyć, że wiele kategorii jest nierozłącznych, a mówienie o marginalizacji i ubóstwie w oddzieleniu od wartościowania nie jest możliwe. Zwykle mówienie o braku czegoś przywołuje na myśl fakt, że posiadanie danego dobra czy danej cechy jest pożądane. Wskazywanie na cierpienie ludzi z powodu niemożności zaspokojenia podstawowych potrzeb nie jest wolne od odniesień do godnego życia, uznanego za dobre dla jednostek i grup, niezależnie od tego, jak szeroko to dobro definiujemy. W polskiej debacie na temat wykluczenia i marginalizacji istotne dla analiz było wprowadzenie bogatszego języka opisu problemów wykluczenia i marginalizacji, który odnosił do koncepcji statusu społecznego, partycypacji społecznej, ale też z kulturowych mechanizmów ekskluzji, ograniczonego dostępu do dóbr ${ }^{13}$, czy wprowadzenie języka, który jest głosem samych wykluczonych.

Problem trwale wykluczonych z życia społecznego polega w dużej mierze na tym, że oni nie zdają sobie sprawy, od czego są odsuwani, jak tragiczna jest ich sytuacja. Nie dążą zatem do zmiany, gdyż pozostawiają sobie jedynie ogólny obraz własnej bezużyteczności. Ponieważ sami nie są już zdolni oszacować dotkliwości swojej trudnej sytuacji, potrzebują do tego refleksji innych ludzi. Nie mają jednak świadomości, że taka refleksja przyczyni się do ugruntowania ich wykluczenia. W takim ujęciu zmarginalizowani to ci, którzy sami nie są w stanie wykreować swojej negatywnej etykiety i oczekują, iż inni, lepiej sytuowani, mający prawo do oceny ich stanu, wskażą im ich tragiczną sytuację. Jak zauważa Krzysztof Frysztacki:

Co najmniej jedna strona zagadnień ekskluzji (i - w następstwie - inkluzji) zdaje się na wstępie prosta i niekwestionowana; mówiąc o wykluczonych, myślimy o „nich”, tych innych, praktycznie oddzielonych od głównego nurtu świata społecznego, żyjących życiem bardziej ograniczonym, naznaczonym deprywacją, gorszym po prostu, może również odstręczająco dziwacznym itd. ${ }^{14}$

Obecnie wiele analiz naukowych, w tym socjologiczne, zakłada różne ujęcia problemu wykluczenia i marginalizacji, a niektóre z nich ukazują ich powszechność ${ }^{15}$, wskazując, że każdy z nas jest w jakimś stopniu wykluczony, wyłączony z czegoś, z powodu braku odpowiednich zasobów. Takie ujęcie, zakładające wszechobecność wykluczenia, bazuje raczej na różnorodności życia społecznego, a nie na nierównościach społecznych. Ograniczenie uczestnictwa w danych obszarach życia społecznego może być warunkowane nie monopolizacją, a odmiennością oczekiwań, kompetencji czy wreszcie różnorodnością ról.

Analizując problemy wykluczenia i marginalizacji w odniesieniu do życia społecznego, można jednoznacznie stwierdzić, że są one skomplikowane. Charaktery-

\footnotetext{
${ }^{13}$ Ibidem.

${ }^{14}$ K. Frysztacki, Socjologia problemów społecznych, Scholar, Warszawa 2009, s. 148.

${ }^{15}$ K.W. Frieske (red.), Marginalność..., s. 27.
} 
styki wykluczenia i marginalizacji wprowadzają różnorodne jej rozumienie. Należy dostrzec, że od wielu lat opracowania wskazują na grupy marginalne, włączając w ich obszar np. włóczęgów, bezrobotnych, ludzi żyjących z pracy dorywczej, z datków otrzymywanych od darczyńców. To ugruntowane podejście traktujące ludzi ubogich jako wykluczonych jest niezmienne. Współcześnie społeczności tolerują wprawdzie ludzi marginalizowanych z powodu ubóstwa, jednak o tyle, o ile spełniają oni określone funkcje, uznawane wprawdzie za potrzebne, jednak niecieszące się uznaniem, a nawet pogardzane. Przywodzi to na myśl np. zbieraczy złomu, odpadów, innych surowców wtórnych, których działanie wskazuje na użyteczność w porządkowaniu przestrzeni, a są to zajęcia, których podjęłoby się niewielu. Herbert Gans badając ubóstwo, wskazuje na różnorodne role, które pełnią ludzie ubodzy w społeczeństwie, choć sami rzadko mają świadomość tej użyteczności ${ }^{16}$. Jak pisał Stefan Czarnowski: „Są to przede wszystkim usługi społecznie niezorganizowane, natury dorywczej lub prywatnej, oraz te, dla których społeczność nie wytworzyła lub nie zdołała wytworzyć organów działających zadowalająco"17. Także wskazania na konkretne przykłady ludzi marginalizowanych z powodu ubóstwa dotyczą ich użyteczności jako konsumentów towarów najniższej jakości, przeterminowanych lub posiadających defekty. Znamienny jest fakt, iż współczesne analizy marginalizacji odwracają znaczenie określania „ludzi zbędnych” jako tych, którzy przyczyniają się do przemocy i destabilizacji, na ludzi wykluczonych, którzy raczej doświadczają przemocy (choćby symbolicznej) ze strony społecznej widowni. Są to obecnie bardziej wskazania na marginalizację, jako wynik przemian społecznych, niż jako potencjał ruchów na rzecz zmian. Niezależnie od przyczyny negatywnego stanu, dla określenia osób żyjących na marginesie społeczeństwa używa się pojęcia grup marginalnych, co nie jest jednoznaczne socjologicznie. Termin „grupa” narzuca bowiem w socjologicznym rozumieniu myślenie o konkretnej strukturze, charakteryzującej się takimi cechami, które znacznie łagodzą dotkliwość stanu wykluczonych. Godne uwagi są w tej mierze wszelkie ogólne sformułowania, charakterystyczne dla proponowanych definicji opisowych problemu. Przykładem jest stwierdzenie, iż „grupa marginalna powstaje w drodze pozbawienia jej równych z innymi praw, władzy, dóbr materialnych i duchowych”"18.

W szerszej analizie można dostrzec, iż jednostki marginalne są raczej ofiarami decyzji innych osób o ich wykluczeniu, którzy w swych wyrokach odbierają komuś np. prawa bądź uniemożliwiają działanie na takich samych prawach ,jak inni”. U podstaw tych stwierdzeń leży błędne założenie o równych prawach dla wszyst-

${ }^{16}$ H. Gans, O niektórych funkcjach ubóstwa, „Polityka Społeczna” 9/1994, ss. 14-16.

17 S. Czarnowski, Ludzie zbędni w służbie przemocy, w: J. Szacki (red.), Sto lat socjologii polskiej. Od Supińskiego do Szczepańskiego. Wybór tekstów, Wydawnictwo Naukowe PWN, Warszawa 1995, s. 483.

${ }^{18}$ F. Mahler, Marginality and Maldevelopment, w: J. Danecki (red.), Insights into Maldevelopment. Insights into Maldevelopment. Reconsidering the Idea of Progress, The University of Warsaw, Warsaw 1993, s. 193. 
kich, niezależnie od różnej sytuacji społecznej jednostek. O ile równość ta dotyczy praw niezbywalnych, przysługujących każdemu człowiekowi, o tyle nie może dotyczyć praw nabywanych ze względu na pewne posiadane cechy, umiejętności, wiedzę itp. Logiczną konsekwencją nadawania praw jednym nie jest pozbawianie tych praw innych ludzi. Nieposiadanie równych praw może być rozpatrywane w kategoriach różnorodności, a nie nierówności i być właśnie oznaką sprawiedliwości, a nie dyskryminacji. Podobnie rzecz się ma z innymi wskazanymi przez Freda Mahlera sferami - posiadania władzy, dóbr materialnych czy duchowych, których dystrybucja może być podstawą wykluczenia i marginalizacji.

Pojawienie się zmarginalizowanych grup społecznych jest związane z nierównościami społecznymi, a nie jak ujmują to niektóre analizy teoretyczne, ze zróżnicowaniem społecznym. To ostatnie stanowi bowiem cechę endemiczną wielu grup i społeczności, jest ono najczęściej traktowane jako konieczne, będąc bezpośrednią konsekwencją różnorodności. Poczucie zróżnicowania społecznego może być konsekwencją odmiennego wsparcia i pomocy kierowanej do różnych kategorii społecznych, np. starszych, z niepełnosprawnościami czy dzieci w systemie edukacyjnym ze specjalnymi potrzebami, co jest zwykle społecznie aprobowane ${ }^{19}$. Natomiast wskazując na związek marginalizacji z nierównościami społecznymi, podkreśla się niesprawiedliwość konsekwencji ich istnienia dla wielu jednostek, zwłaszcza jeśli mowa o tzw. nierównościach niezawinionych, przypadkowych, nieprzewidywalnych i głęboko dystansujących grupy społeczne.

Ogromne znaczenie w wykluczaniu i marginalizowaniu ma społeczne otoczenie, które uruchamia procesy kontroli i reakcji społecznej wobec innych. Dlatego aby marginalizacja mogła społecznie zaistnieć, musi najpierw być dostrzeżona cecha, która będzie określała stan dyskredytujący. Jednostka zostaje tym samym w jakiś sposób napiętnowana, jest to początek procesu wykluczania, a w konsekwencji prowadzi do ugruntowania negatywnego stanu. Ten proces wskazuje, iż nie może zaistnieć tzw. automarginalizowanie przez jednostkę w oderwaniu od kontekstu społecznego. Widoczna tu analogia do koncepcji naznaczania społecznego pokazuje, że społeczna reakcja wymusza na jednostce zgodę na rolę wykluczonego, w czym należy poszukiwać obszaru automarginalizacji jako konsekwencji społecznego działania. Aprobata wymuszona przez okoliczności zewnętrzne (presję społeczną) powoduje wtórne naznaczanie - zgodę na rolę wykluczonego. Analogia do procesu nabywania piętna jest istotna, ponieważ wyjaśnia powody trwałości zaistniałego stanu wykluczenia.

Analizy teoretyczne ujmują wykluczenie i marginalizację jako kategorię opisującą ogólne stany braku społecznego uczestnictwa, ale też pojawiają się analizy ukazujące różne rodzaje wykluczenia i marginalizacji. Analizy teoretyczne najczę-

${ }^{19}$ Zob. M. Ślusarczyk, Transnarodowe życie rodzin. Na przykładzie polskich migrantów w Norwegii, Wydawnictwo Uniwersytetu Jagiellońskiego, Kraków 2019, s. 165 nn. 
ściej skupiają się wówczas na podziale sfer, jakich problem marginalizacji dotyczy. Są to np. wskazywane przez Gino Germaniego m.in.:

- sfera wytwórczości, związana z różnymi stopniami zatrudnienia, biorąc pod uwagę jego trwałość, stosunek do pracy;

- sfera spożycia, w znaczeniu konsumpcji - uczestniczenie w dobrach i usługach;

- sfera kultury - jako wszelkie sposoby interakcji, które upośledzają możliwości pełnienia ról społecznych;

- sfera oświaty - związana z możliwością kształcenia, dostępnością do literatury, sztuki;

- sfera polityki - związana z podejmowaniem decyzji, z realizacją praw obywatelskich;

- sfera socjalna - jako możliwość dbania o zdrowie, poziom życia, dostęp do społecznej opieki ${ }^{20}$.

Wskazane przez autora sfery są jednak tylko wybranymi obszarami życia społecznego. Są to obszary nierozłączne, wzajemnie się warunkujące. Pokazują różnorodność możliwych deprywacji, jednak poza zasięgiem tych wskazań jest ukazanie różnorodności sytuacji jednostek czy grup, które w różnym stopniu mogą być dotknięte problemem marginalizacji we wskazanym obszarze. Stąd jako jednoznacznie porządkujące jest wskazanie na rodzaje marginalizacji, niezależnie od obszarów, w których występują. We wskazaniach, jakie poczynił Germani, trudno bowiem oddzielić sferę kultury i oświaty czy sferę socjalną od politycznej. Oświata, jak ją określa autor, związana z dostępnością do wybranych dzieł, to niejako kwestia technicznego zorganizowania przepływu dóbr, jednak jest to sfera ograniczona często nie samą dostępnością dla jednostek, ale także nieumiejętnością korzystania z oferowanych możliwości.

Ważne jest, aby w analizach wykluczenia i marginalizacji mieć na względzie, co zostało już wskazane, że marginalizacja poprzedzona jest działaniem społecznym, a nie jednostkowym, a nie zaistniałaby, gdyby nie istniała presja koniecznej identyfikacji z tym, z czym identyfikuje się dana grupa. Samo pozwolenie na odmienność niekoniecznie prowokowałoby nierówności. Sytuacja, o której pisze Germani, jest przekonująca, o ile poczyni się dodatkowe założenia, np. że to dana jednostka/grupa samodzielnie podejmuje decyzję o nieutożsamianiu się z szerszą społecznością, a jej decyzja jest wyborem, a nie wynikiem odrzucenia ze strony innych. Zwrócenie uwagi na ten aspekt jest ważne, ponieważ to właśnie społeczne oddziaływanie na jednostkę czy grupę powoduje poczucie obcości (nieidentyfikowania się). Obszary, z którymi jednostka się nie identyfikuje, są związane z prawomocnymi wzorami, normami, wartościami społecznymi. Gdyby tak nie było, mogłoby okazać się paradoksalnie, że to właśnie brak identyfikowania się z tym, co nieprawomocne jest podstawą potwierdzenia przynależności do społeczeństwa, a nie marginalizacji.

${ }^{20}$ G. Germani, Marginality. Transaction Books, New Brunswick, New Jersey 1980. 
W obliczu różnorakich wskazań dotyczących definiowania wykluczenia i marginalizacji najbardziej użyteczne są te, które starają się uchwycić problem w kategoriach ogólnych na tyle, aby mogły one być stosowalne do różnych sytuacji deprywacji. Wprawdzie takie ujmowanie nastręcza wiele problemów, pozwala jednak nie wymieniać jednostkowych sytuacji, które ze względu na swą nietypowość nie dają się jednoznacznie scharakteryzować jako stan wykluczenia. Propozycje takie uwzględniają koncepcje Mahlera, który wskazując ogólne cechy grup wykluczonych, charakteryzuje ich sytuację jako „pozbawienie władzy i dostępu do podejmowania decyzji; posiadanie mniejszego zakresu uprawnień przy większym zakresie obowiązków; mniejsze możliwości wyboru, a więcej przymusu; mniejsze szanse i gorsza sytuacja ekonomiczna; niższe możliwości wykształcenia, zawodowe, wypoczynku itd.; większe wystawienie na nacisk społeczny i na kryzysy; dyskryminacja w systemie prawa oraz napiętnowanie i dyskryminowanie"21.

Definiowanie wykluczenia i marginalizacji w odniesieniu do realnych problemów jest zabiegiem niezwykle trudnym. Nie jest jednoznaczne, czy należy przy analizach brać pod uwagę szerszy kontekst wartości, pomijając ten, jaki panuje w danym społeczeństwie i jest uznawany za prawomocny, czy też należy obiektywizować jej istotę bez takich odniesień, choć przecież mówiąc, że marginalizacja wiąże się z niemożnością działania, nie mamy na myśli działania w ogóle, ale jego konkretny, pożądany obszar; mówiąc o nieumiejętności korzystania jednostek z przysługujących im praw, mamy na myśli konkretne prawa itd. Dodatkowym utrudnieniem w tak przyjmowanej marginalizacji jest odwołanie się do wartości, jako jedynie idealnych wyobrażeń jednostek. Tymczasem powinny być one rozumiane jako realnie istniejące, przejawiające się w działaniu jednostek.

Bez wątpienia różne sfery życia jednostek podlegają odmiennej ocenie, jednak zazwyczaj świadomość istnienia w ich ramach szczególnych społecznych oczekiwań powoduje wzmożenie odczuwania dotkliwości problemów wykluczenia, marginalizacji. Znaczącą rolę w mniej dotkliwym odbieraniu własnej sytuacji odgrywa także możliwość znalezienia obszaru kompensującego daną deprywację. Podobnie jak w sytuacji ubóstwa, tak i w marginalizacji nie tyle istotny jest sam stan deprywacji, ile poczucie z tego powodu niestabilności życiowej, która może się zmieniać na jeszcze bardziej niekorzystny stan.

\section{Literatura}

Czarnowski S., Ludzie zbędni w służbie przemocy, w: J. Szacki (red.), Sto lat socjologii polskiej. Od Supińskiego do Szczepańskiego. Wybór tekstów, Wydawnictwo Naukowe PWN, Warszawa 1995.

Firlit-Fesnak G., Bieda i płeć. Sfery podziału kreujq̨ce ubóstwo kobiet w krajach Unii Europejskiej, Oficyna Wydawnicza Aspra-JR, Warszawa 2015.

${ }^{21}$ F. Mahler, Marginality and Maldevelopment, s. 193. 
Frieske K. W. (red.), Marginalność i procesy marginalizacji, IFiS PAN, Warszawa 1999.

Frysztacki K., Socjologia problemów społecznych, Scholar, Warszawa 2009.

Gans H., O niektórych funkcjach ubóstwa, „Polityka Społeczna” 9/1994.

Germani G., Marginality. Transaction Books, New Brunswick, New Jersey 1980.

Kowalak T., Marginalność i marginalizacja społeczna, Dom Wydawniczy Elipsa, Warszawa 1998.

Mahler F., Marginality and Maldevelopment, w: J. Danecki (red.), Insights into Maldevelopment, Insights into Maldevelopment. Reconsidering the Idea of Progress, The University of Warsaw, Warsaw 1993.

Michel M., Gry uliczne w wykluczenie społeczne w przestrzeni miejskiej. Perspektywa resocjalizacyjna, Wydawnictwo Uniwersytetu Jagiellońskiego, Kraków 2016.

Minois G., Historia samotności i samotników, Aletheia, Warszawa 2018.

Park R.E., Human Migration and the Marginal Man, „American Journal of Sociology” 33(8)/1928.

Piorunek M. (red.), Społeczne i jednostkowe konteksty pomocy, wsparcia społecznego i poradnictwa, t. 1, Wydawnictwo Naukowe UAM, Poznań 2018.

Ślusarczyk M., Transnarodowe życie rodzin. Na przykładzie polskich migrantów w Norwegii, Wydawnictwo Uniwersytetu Jagiellońskiego, Kraków 2019.

Tarkowska E., Ubóstwo i wykluczenie społeczne. Koncepcje i polskie problemy, w: J. Wasilewski (red.), Współczesne społeczeństwo polskie. Dynamika zmian, Scholar, Warszawa 2006.

Tischner J., Filozofia dramatu, Znak, Kraków 1999.

Wnuk-Lipiński E., Socjologia życia publicznego, Scholar, Warszawa 2005. 